\title{
STATCOM - A Preface to Power Quality in Power Systems Performance
}

\author{
Rajendrasinh Jadeja \\ Faculty of Engineering, \\ Marwadi Education Foundation \\ Rajkot, India \\ rajendrasinh.jadeja@ \\ marwadieducation.edu.in
}

\author{
Shital Patel \\ Research Scholar \\ School of Engineering, R. K. \\ University \\ Rajkot, India \\ shital_elect@yahoo.com
}

\author{
Siddharthsingh K. Chauhan \\ Faculty of Engineering, \\ Marwadi Education Foundation \\ Rajkot, India \\ siddhartsingh.chauhan@ \\ marwadieducation.edu.in
}

\begin{abstract}
This paper investigates different types of Flexible AC transmission System (FACTS) controllers with focus on various operational and control aspects of static synchronous compensators (STATCOM) to different performance characteristics like power transfer capability, voltage regulation, reactive power management, stability limits, power factor improvement etc. In addition, various features related to STATCOM like converter topologies, reference compensating signal generation schemes, controllers, and generation of switching signals are reviewed.
\end{abstract}

Keywords-Power Quality; STATCOM; Multilevel Voltage Source Converter; Harmonic

\section{INTRODUCTION}

Electrical power systems are stretching to their operational limits to meet growing demand. An added issue is power quality, as more and more nonlinear loads connect to the grid. Several large power swings and outages can be largely attributed to lack of awareness about system condition as well as inadequate understanding of power quality [1-2]. Several researchers have tried to address the issues that fall under the term of power quality. Even though there is not a strict universal definition, power quality can be considered as a set of various parameters like voltage/current magnitude variation, voltage fluctuation, voltage/current unbalance, harmonic voltage/ current distortion, high frequency voltage noise [3-4].

Flexible AC transmission systems (FACTS) due to their higher controlling capability and quick response have become an area of research with increased interest. Many researchers have developed FACTS controllers to mitigate different power system problems such as voltage unbalance, poor power factor, voltage sag/swell, reactive power compensation, harmonics etc. These controllers are adaptive to various operational conditions and competent to improve the usage of existing installations. This paper provides a thorough review on the topic, focused on Static Synchronous Compensators (STATCOM).

\section{FACTS CONTROLLERS -TYPES \& PERFORMANCE ANALYSIS}

FACTS controllers due to their competency in governing the operation of transmission system by control of interdependent system parameters like power flow control, transmission capability, reactive power control, power quality improvement, etc. have become a key area of research. FACTS controllers were proposed in [5-8]. Depending upon the technological advancements FACTS controllers are segregated into two generations: the first that uses conventional thyristor switched capacitors, reactors tap changing transformers and the second that uses GTOs, MOSFETs, IGBTs etc. [9-18]. Both generations of FACTS controllers have distinct operating characteristics with the operation of first generation controllers restricted to reactive power control only, whereas the second generation controllers were able to control both active as well as reactive power flow, of the transmission system[19-21]. Based on connection with the grid, FACTS controllers are classified as series shunt and combined controllers. Figure 1 depicts statistics of FACTS controller installed worldwide. Performance analysis for different types of FACTS controllers is presented in Table I.

\section{FACTS Controller Installation Worldwide}

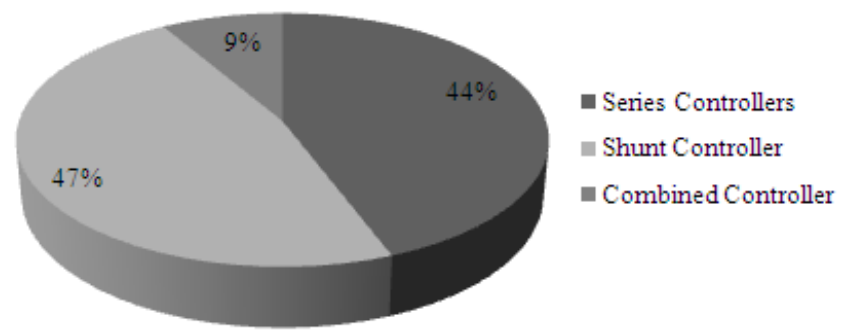

Fig. 1. FACTS Controller Installation Worldwide

\section{DEVELOPMENT AND RESEARCH INTEREST OF STATCOM}

STATCOM is the original shunt connected controller and falls amongst the FACTS Controllers. In 1976 Gyugyi anticipated the idea of power flow control through STATCOM. As per IEEE definition static synchronous compensator is competent to control capacitive or inductive output current independent of system voltage [1]. The entire power flow control is achieved by injection or absorption of controlled reactive power into/from the power system. At the time of lapse in system voltage STATCOM feeds reactive power 
(capacitive) and during increased system voltage STATCOM takes up reactive power (inductive) [2]. Figure 2 is an indicative of the research work being carried out in the area of STATCOM applications. It is clearly depicted from Figure 2 that most research work has been carried out on the usage of STATCOM for voltage control in power system. It is shown that STATCOM application for voltage control in power system has increased in the past decade. This also reflects the extensive utilization of STATCOM in power system stability and power quality issues. It is also shown that STATCOM application in renewable energy has also increased significantly.

TABLE I. PERFORMANCE ANALYSIS OF FACTS CONTROLLERS

\begin{tabular}{|c|c|c|c|c|c|c|c|}
\hline & SVC & TCSC & TCPST & STATCOM & SSSC & UPFC & IPFC \\
\hline MVA Capacity & Best & Best & Good & Better & Better & Better & Better \\
\hline Reactive Power Control & Good & Better & Better & Good & Best & Best & Best \\
\hline Voltage Control & Best & Good & Good & Best & Good & Better & Better \\
\hline Thermal Stability & Good & Better & Good & Good & Better & Best & Best \\
\hline Transmission Competency & Good & Best & Better & Good & Best & Best & Best \\
\hline Transient Stability & Good & Best & Better & Better & Best & Best & Best \\
\hline Investment Cost & Good & Good & Better & Better & Better & Best & Best \\
\hline Converter Loss & Better & Good & Good & Better & Better & Best & Best \\
\hline Expected Operational Life & Best & Better & Better & Best & Better & Better & Better \\
\hline Installations till date & Best & Best & Better & Best & Better & Good & Good \\
\hline Future Trends & Better & Better & Better & Best & Best & Best & Best \\
\hline
\end{tabular}

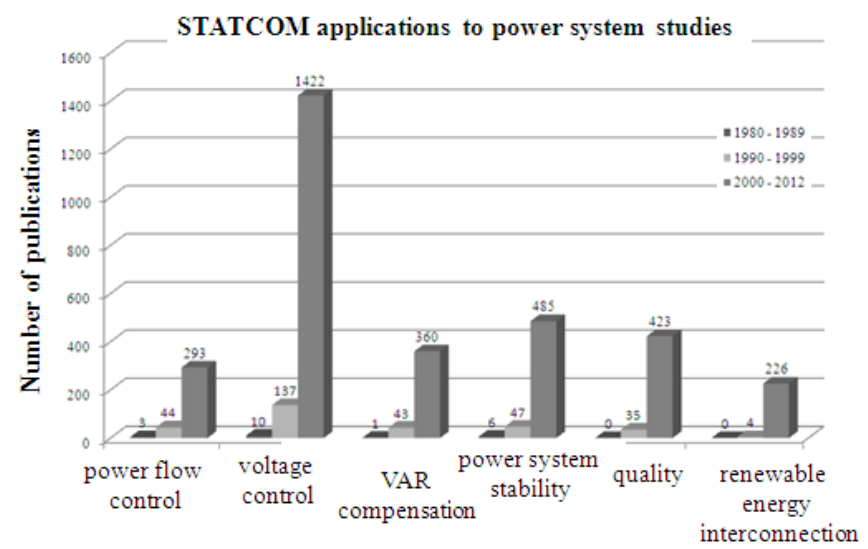

Fig. 2. STATCOM growth (publications in the IEEE/IEE library)

\section{STATCOM COMPONENT}

STATCOM controllers achieve active as well as reactive power control by injecting current in to the line at the point of common coupling. Saha et al, have presented various topologies and control algorithms for STATCOM [22]. Also, the FACTS program sponsored by Electrical Power Research Institute (EPRI) identifies the significant challenges faced by the FACTS technology and their proposed solutions [23]. Various applications of shunt controllers have been studied and reported in literature [24-25]. Controllable reactive power can be generated by all types of DC to AC switching converters (voltage source and current source converters). However due to issues like high conduction losses, additional over voltage protection and higher voltage rating for the semiconductor in current source converter, voltage source converter is popular in power system application like FACTS controllers, especially STATCOM. A controlled three phase voltage of power frequency is produced by sequential switching of power semiconductor devices. The power flow either from line to controller or controller to line is due to DC charged capacitor at input side of converter. Each output voltage of converter is in phase with line voltage due to small tie reactance linking converter and line. Conventionally two-level VSC are used for STATCOM, however, nowadays multi-level VSC due to its modularity in structure and power handling capability are quickly replacing two-level VSCs for STATCOM [26-39].

\section{A. Multilevel Voltage Source Converter Topologies for STATCOM}

Multilevel converters have substituted the traditional converters due to structure modularity and low total harmonic distortion (THD). Components required per leg for different multilevel converter topology are listed in Table II.

TABLE II. COMPONENT PER LEG OF MULTILEVEL VOLTAGE SOURCE CONVERTER

\begin{tabular}{|c|c|c|c|}
\hline Converter Type & Diode Clamp & Flying Capacitor & Cascaded \\
\hline $\begin{array}{c}\text { Main Switching } \\
\text { Device }\end{array}$ & $(\mathrm{m}-1) \times 2$ & $(\mathrm{~m}-1) \times 2$ & $(\mathrm{~m}-1) \times 2$ \\
\hline Main Diode & $(\mathrm{m}-1) \times 2$ & $(\mathrm{~m}-1) \times 2$ & $(\mathrm{~m}-1) \times 2$ \\
\hline $\begin{array}{c}\text { DC Bus } \\
\text { Capacitor }\end{array}$ & $(\mathrm{m}-1)$ & $(\mathrm{m}-1)$ & $(\mathrm{m}-1) / 2$ \\
\hline $\begin{array}{c}\text { Balancing } \\
\text { Capacitor }\end{array}$ & 0 & $(\mathrm{~m}-1) \times(\mathrm{m}-2) / 2$ & 0 \\
\hline Clamping Diode & $\begin{array}{c}(\mathrm{m}-1) \times \\
(\mathrm{m}-2)\end{array}$ & 0 & 0 \\
\hline
\end{tabular}

\section{1) Diode Clamped Multilevel Converter}

Extensive number of clamping diode and balancing of DC link voltage are the two major issues that made diode clamped multilevel inverter less popular. Diode-clamped converter with virtual vector based modulation [40] and space vector pulse width modulation [41] for DC link voltage balancing algorithm has been proposed with experimental results. Dupuis and Okou have proposed a novel approach for DC link voltage balancing based on sub-controller [42]. STATCOM output voltage is supposed to be controlled by: terminal voltage sub-controller, neutral-point sub controller alleviate neutral point and two more auxiliary controllers maintain DC capacitor voltage [42]. A method to find the state space model for a general N-level 
diode clamped converter evaluated with simulation can be found in [43]. Voltage balancing between different capacitors with the use of an auxiliary capacitor in diode clamped multilevel converters is discussed and compared with traditional methods [44-45]. A combine diode-clamp cascade multilevel converter topology is suggested, where multilevel principal synthesizes output voltage with sub-harmonic PWM technique [46] and advantage of fewer numbers of clamping diodes helps in cost and size reduction [47]. Increased use of power electronics application, wind energy application and solar photovoltaic application, multi-level converters are designed for specific duty cycle, optimal balancing strategy, reduced switching strategy and specific modulation approach [48-54].

\section{2) Flying Capacitor Multilevel Converter}

With the large amount of energy storage capability during power outage, prevalent real and reactive power flow control and low harmonic content the flying capacitors multilevel converters have been accepted in FACTS control application. The only difficulty is that the excessive number of storage capacitors complicates converter control for real power transmission and capacitor voltage balancing issue [55-56]. The conventional flying capacitor multilevel converter performance can be improved by replacing the clamping capacitors by a number of series connected half bridge cells which will generate voltage at the converter output [57]. The measurement of voltage and selection of suitable switching states can control harmonic content of generated wave form, switching frequency and load impedance. A closed loop control based on phase shifted SPWM strategy with adjustment in switching time of selected switching states or selective harmonic elimination pulse-width modulation control has improved the selfbalancing characteristics of the converter [58-60] and this can be achieved by adding two low frequency switches and capacitors [61]. The combined conventional flying capacitor multilevel converter with two level bridges is proposed in [62] and its soundness is checked with simulation. Also semi bridge converter with reduced switch count and free phase leg structure is used for unity power factor application [63].

Output voltage vector method for swapping of two switch modes which uses charging current in flying capacitor multilevel inverter is developed and simulation results are derived [64]. The number and size of flying capacitor limits use of converter. As a solution of this converter with multiple duty cycles with modulation technique in direct response to the capacitor voltage is explored [65-66]. A synchronous reference frame control is also broadly used to control power flow and DC bus voltage unbalance. Ghias et al. have carried out the simulation for back to back flying capacitor converter with reduced DC bus capacitance [67]. A work has been done on average models in abc and $\mathrm{dq} 0$ coordinates which will improve the performance of flying capacitor multi-level converters [6869].

\section{3) Cascaded Multilevel Converter}

Cascaded-multilevel voltage source converter with separate DC source is proving itself an appealing concept due to its modularity in structure [70-72]. Peng et al. have proposed a cascaded 11-level inverter with a control scheme in which swapping pulses P1-P5 at every half cycle makes all DC capacitor voltage equally charged and discharged [73]. Instead of using DC voltage source of same magnitude if a DC voltage source of magnitude ratio 1:2:4:8, the traditional 9-level inverter is switched to 31-level inverter [74]. A six stage, 31level converter of $30 \mathrm{kV}$ with minimum step of $2 \mathrm{kV}$ is simulated and tested on hardware of Railway Power Compensators [75]. Due to generation of medium/ high voltage capacity directly at converter output allows to eliminate the coupling transformer [76]. While in [77], a cascaded transformer for multi-level converter is suggested. This is the concept where, each level of the converter is transformer connected. This idea works for equal power sharing and losses estimation for multi-level converter. In [78] two structures for $11 \mathrm{kV}$ and $33 \mathrm{kV}$ are proposed with 81 and 27 levels. Here two comparative studies are carried out. The one with all cascaded converter of equal size cell and the other with the selection of cell size made on the basis of its DC-link voltage. In terms of their losses results, it is shown that the 27-level, $33 \mathrm{kV}$ converters are superior with equal sized cell while the 81level, $11 \mathrm{kV}$ converters are good with ternary sequence selection of DC-link voltage. Instantaneous power theory for reference current extraction has been executed for multi-level inverter used in wind mill. The approach of the author is to analyze dynamic response of STATCOM for constant speed wind turbine [79]. Modular structure of cascaded multilevel inverter with two full-bridge units in parallel with two halfbridge units with single control loop to control both DC link voltage [80] and to improve power factor [81] has been obtained.

The addition of two controllable diodes in each cell to reduce voltage ripple is a novel technique proposed in [82]. Multilevel converters made of cascaded cells energy storage systems integrated with conventional topology or with integer/non-integer DC voltage ratio or dynamically varying voltage ratio have made multi-level converter application more attractive [83-86]. A concept of sub-multilevel converter blocks is explored with reduced number of switches and capacitors through experimental result in [87-89]. An asymmetrical 147level converter topology with sub-multi-level arrangement is proposed. The objective of this converter is to improve its' performance for DVR. Together with conventional number of switches at each level, two additional switches between two DC sources are used to generate more number of level in [90]. Reference [91] deals with the elimination of DC components of current in coupling transformer secondary due to core saturation issues. Authors have proposed two methods to achieve this: either reduce the positive half cycle area by keeping the negative half cycle area constant or reduce the positive half cycle area by increasing the negative half cycle area. Experimental results are derived for $154 \mathrm{kV}, \pm 50 \mathrm{MVAR}$, T-STATCOM.

A digital controller parallel to $\mathrm{PD}$ and repetitive control is simulated by $\mathrm{Xu}$ et al. in [92]. To achieve DC link voltage regulation, low THD, redundancy and reductions in cost; modular multilevel converter topologies like single star bridge cells, single delta bridge cells, double star bridge cells etc. for drives and PV solar system are discussed in [93-94]. The multilevel converter topology generally uses the fundamental 
switching frequency modulation method and the high frequency PWM method [95]. An accurately designed switching scheme can further reduce converter losses, size of inductor and DC capacitor. As a harmonic elimination technique, it gives better result compared to other techniques, but its complexity in deciding the parameter rating increases as the levels of the inverter increase [96-98]. Reference [99] shows the comparative simulation studies of Sine-Wave Pulse Width Modulation (SPWM) and Optimized Hybrid Phase Disposition Method (OHPDPWM) to measure the effectiveness of STATOM control. DC voltage balancing with phase shifted sinusoidal pulse width modulation (PS-SPWM) technique for cascaded multilevel converter by means of experimental result is proposed in [100-103]. This scheme helps out to eliminate weighty transformer and reduces converter power loss. Sinusoidal pulse width modulation (SPWM) with carrier phase-shifting, unipolar phase-shifting, reversing voltage etc. for STATCOM to reduce THD and switching frequency is discussed in [104-106].

\section{B. Controller Design for STATCOM}

For ease the following section is arranged as;

- Pole placement controller technique

- $\quad \mathrm{PI} / \mathrm{PID} / \mathrm{PD}$ controller technique

- DC-link balancing controller technique

- Hysteresis band controller technique

This however, doesn't mean that the above mentioned controller techniques are the only solutions. Researchers are continuously updating previous concepts by amalgamating existing one. Pole placement controller design with two set of controller gain i.e. first gain, by the use of linear matrix inequalities (LMIs) to meet design specification and second gain, by the use of zero set to meet overall system voltage control [107], first gain with one modulation index for steady state and second gain with adaptive modulation index for transient [108], combine Linear-Quadratic Regulator (LQR) [109] etc. are discussed for improving the operation of STATCOM.

In the environment of damping power systems oscillations, two controllers which regulate DC voltage and AC voltage using the optimal pole shifting (OPS) technique [110] are proposed. Also, the same concept but with fixed modulation index (MI) and variable dc capacitor voltage reference is implemented for STATCOM in [111]. Single machine infinite bus and two area four machine system for damping control by the nonlinear matrix inequalities is proposed in [112] with tested closed-loop performance under three phase fault and small signal disturbances. Reference [113] has come up with the exact linearization method to transform the nonlinear threedimension equations with proportional integral control. Simulation results are derived for STATCOM operation for three phase ground fault too. A Ho loop shaping technique [114] for voltage magnitude and angle controller is identified and compared with a PID controller using pole placement method for gain derivation. Rule based controller, which utilizes fuzzy logic, bang-bang, root counting theory, self- tuning PI with particle swarm optimization etc. are proposed over a fixed parameter PI control to enhance the improved performance of controller [115-117]. Behavior of SSSC and STATCOM on single machine infinite bus [118] and SVC and STATCOM with usual lead - lag controller [119] with particle swarm optimization for dynamic stability performance has been proposed. The result proves that the SSSC offers fast dynamic recovery amongst all three. An adaptive PI controller is designed to maintain the voltage at point of common coupling for a range of instability. For the intended change in the gain of PI controller a cautious study of previous gain, practical gain and global is done for the algorithm [120-121].A self-tuning STATCOM with PI controller based on real time data adoption and gain setting with pole placement technique for different loading condition is designed and simulated [122123]. A direct axis current control for any PI, PID or Adaptive mechanism is proposed in [124]. Simulation results are compared for controller output voltage variations when reactive power demand does not exceed limits and when reactive power demand exceeds them.

Particle swarm optimization technique for $\mathrm{AC} / \mathrm{DC}$ voltage regulation, AC/DC damping controller, power system stabilizer on the single bus system with several fault condition with simulation result is investigated in [125]. In [126] transient stability is improved using Euler-Lagrange method based on passivity, where setting of PI controller $\mathrm{Kpd}=0.01$, $\mathrm{Kid}=0.3$, $\mathrm{Kpq}=2$ and $\mathrm{Kiq}=10$ and in [127-128] a back to back STATCOM based on passivity controller with PWM based rectifier section and multipulse inverter section is proposed. Whereas in [129] sliding mode technique is adopted where inner loop performs for switching of VSC and outer loop performs for AC and DC side voltage control. A decoupled controller with pole placement technique having an inverter voltage of $480 \mathrm{~V}$ and a reference reactive power of $1000 \mathrm{VAR}$ is tested for reactive power change up to 5000 VAR. While doing so the capacitor voltage variation is very small [130]. A various approach supporting zero set technique, additional current feedback, phase-lead compensation, and series passive compensation, shunt active compensation etc. are conceded to study system dynamic [131-135]. In the case of [136] CT behavior is analyzed for cascaded multilevel inverter feedback loop. Voltage compensation at far end of line is experimented by $8 \mathrm{kVA}, 415 \mathrm{~V}$ STATCOM. The results are strongly matched with speculative framework as voltage sag is reduced by $39 \%$ for the STATCOM designed at $25 \%$ of rated load [137], while in [138] an attempt to integrate power converter with digital controller equipped with optical interface is described. This local controller is also capable of sensing signal and sending them back to the power converter via a serial port.

Mohan et al. have worked out the issues related to practical implementation of STATCOM for voltage regulation through estimation of load conductance with feedback control. They have modeled STATCOM as an instantaneous reactive current source which controls DC bus voltage with tolerable value of charging and discharging current [139-143]. Singh et al. has come up with low THD, 48-pulse, voltage source converter. The uniqueness is achieved by 8 set of double star connected $2-$ level converter topology. The phase angle difference between two star connections can control reactive power [144]. 
DC capacitor voltage balancing with swapping switching pattern for fixed time period only has been proposed in [145148]. Here two series H-bridge five level converter is simulated and tested on prototype. At some instant the swapping of switch may introduce redundant switching loss and phase shift in voltage. This limitation is overshoot by small signal model and dead band controller where controller is designed to work in capacitive, inductive and standby mode with changing frequency of $120 \mathrm{~Hz}$ [145-148].

A wide area control technique for 12-bus STATCOM is proposed in [149] capable of controlling large power disturbance. At the time of operation, the controller generates two signals, one for AVR of generator and second for STATCOM. These will together look up the damping of generator rotor during interruption and restoration too whereas in [150] an automatic gain controller is designed for a gain $0<\mathrm{k} \leq 1$. Stability enhancement with less variation in DC voltage is the key issue while designing a controller. In [151154] an attempt to offer the solution for the above said problem via modified invasive weed optimization (MIWO) algorithm, back to back STATCOM or loop-shaping technique is presented. A repetitive controller is endowing with the conventional PI controller to trail or refuse the signal with moderate steady state error. For abrupt changes in load the output of the repetitive controller is constant which offers effectiveness in power factor improvement and DC voltage stabilization [155]. STATCOM controller based on RL trial and error is designed. The data is monitored online through six layer fuzzy neural network controller [156]. Floating of DC voltage is a challenging issue for today's FACTS Controllers. In [157-161] the focus is on how to improve the drift in voltage for diode clamped multi-level converter by space vector modulation techniques.

While managing voltage stability or reactive power compensation, inverter losses and harmonics in a STATCOM controller is also a question of research. A multilevel inverter with harmonic elimination method is one of the suggested solutions. But these can malpractice with the change in load condition. In [162-164] the authors had put on the concentration on current harmonics due to resonance, DC voltage ripple due to firing angle of each switch, consequence of coupling transformer. Also a square-wave controller with current feedback and phase lead compensation is proposed. Differential algebra [165] and a loop shaping method with use of hysteresis band are worked out where pre and post comparator shaped to provide a preferred open loop [166-167]. The best input signal is chosen by inspection. Here a complex perturbation is used to compute optimal control. A seven level cascaded multilevel converter is design as standalone system or $\mathrm{H}$-bridge building blocks technique for 1.5 MVA. This model is capable of handling 4.5 to 30 MVA by adding more number of H-bridges [168-169].

In [171], a \pm 75 KVAR, $50 \mathrm{~Hz}$, angle-controlled STATCOM was put up for minute operating rang of angle difference between converter voltage and system voltage. The value of angle is set $\left(-1.5^{\circ}, 1.5^{\circ}\right)$, hence state-space averaging principal provides more accurate results for reactive power compensation [170]. Similarly root locus method [171] and dynamic voltage controller configurations with negative sequence component and phase voltage magnitude is suggested for steady state and dynamic stability [172-173]. An adaptive control that counts the ambiguity in the parameter variation is designed and tested for power factor improvement. Author has also compared adaptive controller test results with conventional vector control test results which satisfy the performance of STATCOM in both the case [174-175]. A comparative analysis is conceded for voltage source converter (VSC) in shunt and series connection applications. Along with this radial basis function network based VSC is proposed and compared with PI controller based VSC for STATCOM, SSSC and UPFC [176177].

High power multipulse, multipoint clamped and chain converter topologies are analyzed on basis of no. of devices, total harmonic distortion, component sizing, capability of voltage control and DC voltage drift. Later on, generalized Nconverter module for $\mathrm{H}$-bridge is presented which uses voltage and current harmonic component to stabilize the DC capacitor voltage. Experiments were executed for two and three modules where second harmonic of line voltage has been adopted for injected component [178-180]. H-bridge cascade multilevel STATCOM with low voltage and $11 \mathrm{kV}$ power rating hardware has been jointly developed by University of Newcastle and ResTech Pty Ltd. Voltage balancing is done by arranging the DC capacitor voltage in incremental order. This will decide the sequence of phase leg to generate the output based on instantaneous real power flow [181-184]. A nonlinear controller based STATCOM on multi-machine power system is designed and simulated for three-phase to ground fault at two different nodes [185]. A special purpose STATCOM for Spallation Neutron Source power beam accelerator at Oak Ridge National Laboratory has been effectively implemented for full rated power [186]. Also for regulation of bus voltage a system stabilizer based on STATCOM is designed on computational optimization approach [187]. \pm 100 MVAR, 132 $\mathrm{kV}$, 48-pulse, 2-level STATCOM is designed to locate at midpoint of line. The reason behind midpoint location is that it requires only four transformers which further reduces size and cost [188].

In [189] superconducting magnetic energy storage coil is integrated with STATCOM operation for three phase to ground fault. The operation of the proposed STATCOM is simulated for voltage control as well as frequency control model. A space vector based 3-zone, 5-zone and 7-zone, PWM technique has been carried out by Narayanet al. The proposed work is to reduce current ripple for inverter used in high-tension lines [190]. Few converters reported for Adjustable speed drives (ASDs), are also reviewed to analyze their probable application in STATCOM. A concept of 5-level inverter has been implemented by cascading one 2-level and one 3-level inverters [191]. Mahadevan et al. team has suggested phaseshifted dual source matrix converter topology [192]

\section{CONCLUSION}

By looking at the number of papers published in recent years, it is easy to conclude that a variety of FACTS controllers is available for evaluating performance in large power systems. 
The research and development activity to obtain accuracy has adequately crossed the threshold. A trend of having more and more advanced FACTS controllers is evident. This paper provides a brief summary of different FACTS controller types and a focus on STATCOM topologies and their control strategies.

\section{REFERENCES}

[1] N. Hingorani, L. Gyugyi, Understanding FACTS-Concepts and Technology of Flexible AC Transmission Systems. Piscataway, NJ: IEEE Press/Wiley, 2000

[2] P. Salmeron, R. S. Herrera, A. Perez, J. Prieto, "Power Quality Evaluation Indices in Three-phase Networks", IEEE Power Tech, St. Petersburg, Russia, pp. 1-6, 2005

[3] C. Sankaran, Power Quality, CRC Press Boca Raton London New York, Washington, DC, 2002

[4] M. H. J. Bollen, Understanding Power Quality Problems-Voltage Sags and Interruptions, IEEE Press/ Standard Publishers Distributors, New Delhi, 2001

[5] N. G. Hingorani, "FACTS-Flexible AC Transmission System", IEEE 5th International Conference on $\mathrm{AC}$ and DC Power Transmission, London, pp. 1-7, 1991

[6] N. G. Hingorani, "Flexible AC Transmission", IEEE Spectrum, Palo Alto, USA, Vol. 30, No. 4, pp. 40-45, 1993

[7] N. G. Hingorani, "High Power Electronics and Flexible AC Transmission System", IEEE Power Engineering Review, Vol. 8, No. 7, pp. 3-4, 1988

[8] B. Singh, K. S. Verma, D. Singh, C. N. Singh, A. Singh, E. Agrawal, R. Dixit, B. Tyagi, "Introduction to FACTS Controllers a Critical Review", International Journal of Electrical Energy Systems, Vol. 3, No. 2, pp. 85-98, 2011

[9] IEEE Power Engineering Society, FACTS Overview. IEEE Special Publication 95TP108, 1995

[10] IEEE Power Engineering Society, FACTS Applications. IEEE Special Publication 96TP116-0, 1996

[11] S. Haddad, A. Haddouche, H. Bouyeda, "The use of FACTS devices in Disturbed Power Systems-Modeling, Interface, and Case Study", International Journal of Computer and Electrical Engineering, Vol. 1, No. 1, pp. 56-60, 2009

[12] W. Qiao, R. G. Harley, G. K. Venayagamoorthy, "Effects of FACTS Devices on a Power System which Includes a Large Wind Farm", IEEE Power Systems Conference and Exposition, Atlanta, Georgia, pp. 2070 2076, 2006

[13] D. Murali, M. Rajaram, N. Reka, "Comparison of FACTS Devices for Power System Stability Enhancement", International Journal of Computer Applications, Vol. 8, No. 4, pp. 30-35, 2010

[14] A. Draou, "An Advanced Static VAR Compensator Based on A Three Level IGBT Inverter Modelling Analysis and Active Power Filtering", Journal of Electrical Engineering, Vol. 63, No. 6, pp. 392-396, 2012

[15] A. Mohanty, A. Barik," Power System Stability Improvement using FACTS Devices", International Journal of Modern Engineering Research, Vol. 1, No .2, pp. 666-672, 2011

[16] R. Somalwar, M. Khemariya, "A Review of Enhancement of Transient Stability by FACTS Devices", International Journal of Emerging Technologies in Sciences and Engineering, Vol. 5, No. 3, pp. 72-76, 2012

[17] F. S. Young," Flexible AC Transmission Systems: Technology for the Future", IEEE 20th Electrical Electronics Insulation Conference, Boston, Massachusetts, pp. 216-219, 1991

[18] R. Grunbaum, T. Podins, "Alleviating Bottlenecks in Power Interconnectors by Means of FACTS", IEEE 7th International Conference-Workshop on Compatibility and Power Electronics, Tallinn, Estonia pp. 155-160, 2011
[19] K. Sen, M. L. Sen, Introduction to FACTS Controllers-Theory, Modeling, And Applications, IEEE Press, A John Wiley \& Sons, Inc., Publication, 2009

[20] K. R. Padiyar, FACTS Controllers in Power Transmission and Distribution, New Age International (P) Limited, Publishers, New Delhi, 2009

[21] E. Acha, R. Claudio, H. Ambriz-Perez, C. Angeles-Camacho, FACTS Modeling and Simulation in Power Networks, John Wiley \& Sons Ltd, England, 2004

[22] R. Saha, A. Chandra, K. Al-Haddad, "Static Synchronous Compensators (STATCOM): A Review”, IET Power Electronics, Vol. 2, No. 4, pp. 297-324, 2009

[23] A. Edris, "FACTS Technology Development: An Update", IEEE Power Engineering Review, Vol. 20, No. 3, pp. 4-9, 2000

[24] B. Kiani, "Review of Novel Control Techniques for STATCOM and its Effects on a Wind Farm", IEEE 9th International Conference on Sustainable Power Generation and Supply, Nanjing, China, pp. 1-5, 2009

[25] Y. Pal, A. Swarup, B. Singh, "A Review of Compensating Type Custom Power Devices for Power Quality Improvement", Joint International Conference on Power System Technology and IEEE Power India Conference, New Delhi, India, pp. 1-8, 2008

[26] Y. Qingguang, P. Li, W. Liu, X. Xie, “Overview of STATCOM Technologies", IEEE International Conference on Electric Utility Deregulation, Restructuring and Power Technologies, Weihai, China, Vol. 2, pp. 647-652, 2004

[27] A. M. Gole, "Dynamic Reactive Compensation: Reactive Power Fundamentals", IEEE Power Systems Conference and Exposition, Phoenix, Arizona, pp. 1-3, 2011

[28] M. Smirnov, R. Grinberg, M. Riabchitsky, Y. Rozanov, "Power Factor Correction and Active Filtering Technology Application for Industrial Power Systems with Non-linear Loads", IEEE 12th International Conference on Power Electronics and Motion Control, Portoroz, Slovenia, pp. 1484-1489, 2006

[29] S. Teleke, A. Yazdani, B. Gudimetla, J. Enslin, J. Castaneda, "Application of STATCOM for Power Quality Improvement", IEEE Power Systems Conference and Exposition, Phoenix, Arizona, pp. 1-6, 2011

[30] B. D. Scott, J. Warner, “ Turning a Generators MVAR's into MW's by Use of Static VAR Compensator", IEEE Conference on Innovative Technologies for an Efficient and Reliable Electricity Supply, Waltham, Massachusetts, pp. 184-187, 2010

[31] A. Abrantes, "Overview of Power Quality Aspects in Wind Generation", IEEE North American Power Symposium, Champaign, Illinois, pp. 1-6, 2012

[32] C. C. Davidson, "Power Transmission with Power Electronics", IEEE 14th European Conference on Power Electronics and Applications, Birmingham, England, pp. 1-10, 2011

[33] B. M. Zhang, Q. F. Ding, "The Development of FACTS and Its Control", IEEE 4th International Conference on Advances in Power System Control, Operation and Management, Hong Kong, Vol. 1, pp. 48-53, 1997

[34] H. K. Tyll, "FACTS Technology for Reactive Power Compensation and System Control", IEEE Transmission and Distribution Conference and Exposition, Latin America, pp. 976-980, 2004

[35] Y. Zhao, "Research on STATCOM Principle and Control Technology", IEEE International Conference on Consumer Electronics, Communications and Networks, Xianning, China, pp. 1593-1596, 2011

[36] G. Reed, J. Paserba, T. Croasdaile, M. Takeda, N. Morishima, Y. Hamasaki, L. Thomas, W. Allard, "STATCOM Application at VELCO Essex Substation", IEEE Transmission and Distribution Conference and Exposition, Atlanta, Georgia, Vol. 2, pp. 1133-1138, 2001

[37] A. Oskouj, B. Mathew, J. Hasler, M. Oliveira, T. Larsson, A. Petersson, E. John, "Holly STATCOM-FACTS to Replace Critical Generation, Operational Experience", IEEE Transmission and Distribution Conference and Exhibition, Dallas, Texas, pp. 1393-1398, 2006 
[38] S. Kolluri, A. Kumar, K. Tinnium, R. Daquila, "Innovative Approach for Solving Dynamic Voltage Stability Problem on the Entergy System" IEEE Power Engineering Society Summer Meeting, Chicago, USA, Vol. 2, pp. 988-993, 2002

[39] T. Masood, N. Al-emadi, S. A. Qureshi, Y. Y. Almulla, A. J. Khan, S. K. Shah, "FACTS Control Devices (STATCOM, SSSC and UPFC) ReConfiguration Techniques by PSIM/MATLAB", IEEE International Conference on Electrical Engineering, Lahore, Pakistan, pp. 1-6, 2007

[40] S. Monge, S. Alepuz , J. Bordonau, J. Peracaula, "Voltage Balancing Control of Diode Clamped Multilevel Converters with Passive FrontEnds", IEEE Transactions on Power Electronics, Vol. 23, No. 4, pp. $1751-1758,2008$

[41] Z. Shu, N. Ding, J. Chen, H. Zhu, X. He, "Multilevel SVPWM with DCLink Capacitor Voltage Balancing Control for Diode Clamped Multilevel Converter based STATCOM", IEEE Transactions on Industrial Electronics, Vol. PP, No. 99, pp. 1-12, 2012

[42] D. Dupuis, F. Okou, "Modeling and Control of A Five Level Diode Clamped Converter Based STATCOM", IEEE International Conference on Industrial Technology, Washington, USA, pp. 1-6, 2009

[43] A. F. Okou, R. Beguenane, D. Nganga-Kouya, D. Dupuis, "A Multivariable Adaptive Nonlinear Controller for a Five-Level Diode Clamped STATCOM", IEEE Conference on Electrical Power and Energy, Winnipeg, Canada, pp. 102-108, 2011

[44] Z. Shu, N. Ding, J. Chen, H. Zhu, X. He, "Voltage Balancing Approaches for Diode-Clamped Multilevel Converters Using Auxiliary Capacitor-Based Circuits", IEEE Transactions on Power Electronics, Vol. 28, No. 5, pp. 2111-2124, 2013

[45] J. Zhao, Y. Han, X. He, C. Tan, J. Cheng, R. Zhao, "Multilevel Circuit Topologies Based on the Switched-Capacitor Converter and DiodeClamped Converter", IEEE Transactions on Power Electronics, Vol. 26 , No. 8, pp. 2127-2136, 2011

[46] K. Ding, Y. Zou, Z. Wang, Z. Wu, Y. Zhang, "A New Diode-Clamp Cascade Multilevel Converter", IEEE 29th Annual Conference by Industrial Electronics Society, Roanoke, USA, Vol. 3, pp. 2566-2569, 2003

[47] Z. Pan, F. Z. Peng, V. Stefanovic, M. Leuthen, "A Diode Clamped Multilevel Converter with Reduced Number of Clamping Diodes", IEEE 19th Annual Conference and Exposition on Applied Power Electronics, Anaheim, California, Vol. 2, pp. 820-824, 2004

[48] A. Nami, F. Zare, G. Ledwich, A. Ghosh, "A New Configuration for Multilevel Converters with Diode Clamped Topology", IEEE International Power Engineering Conference, Singapore, pp. 661-665, 2007

[49] S. R. Minshull, C. M. Bingham, D. A. Stone, M. P. Foster, "A New Switching Scheme for Reduced Switching Frequency and Balanced Capacitor Voltages for Back-To-Back Connected, Diode-Clamped Multilevel Converters", 4th IET Conference on Power Electronics, Machines and Drives, York, England, pp. 636-639, 2008

[50] Y. Cheng, C. Qian, M. L. Crow, S. Pekarek, S. Atcitty, "A Comparison of Diode-Clamped and Cascaded Multilevel Converters for a STATCOM with Energy Storage", IEEE Transactions on Industrial Electronics, Vol. 53, No. 5, pp. 1512-1521, 2006

[51] Z. Chen, X. Xiao, H. Wang, M. Liu, "Analysis of Converter Topological Structure for Direct-Drive Wind Power System with PMSG", IEEE International Conference on Power System Technology, Zhejiang, China, pp. 1-5, 2010

[52] K. A. Corzine, J. R. Baker," Multilevel Voltage-Source Duty-Cycle Modulation: Analysis and Implementation", IEEE Transactions on Industrial Electronics, Vol. 49, No. 5, pp. 1009-1016, 2002

[53] S. A. Gonzalez, M. I. Valla, C. F. Christiansen, "Five-Level Cascade Asymmetric Multilevel Converter", IET Power Electronics, Vol. 120, No. 1, pp. 120-128, 2010

[54] A. Nami, F. Zare, A. Ghosh, F. Blaabjerg "A Hybrid Cascade Converter Topology with Series Connected Symmetrical and Asymmetrical Diode Clamped H-Bridge cells", IEEE Transaction on Power Electronics, Vol. 26, No. 1, pp. 51-65, 2011
[55] J. S. Lai, F. Z. Peng, "Multilevel Converters - A New Breed of Power Converters", IEEE Transactions on Industry Applications, Vol. 32, No. 3, pp. 509-517, 1996

[56] M. Hojo, K. Minato, "Integrated Power Conversion for DC Power System by Flying Capacitor Multi-Level Converter", IEEE International Power Electronics Conference, Sapporo, Japan, pp. 37-342, 2010

[57] G. P. Adam, B. Alaimi, K. H. Ahmed, S. J. Finney, B. W. Williams, "New Flying Capacitor Multilevel Converter", IEEE International Symposium on Industrial Electronics, Gdańsk, Poland, pp. 335-339, 2011

[58] S. Thielemans, T. Vyncke, J. Melkebeek, "Balancing and Harmonic Analysis of Flying Capacitor Multilevel Converters", IEEE 25th Convention of Electrical and Electronics Engineers, Eilat, Israel, pp. 609-613, 2008

[59] C. Feng, J. Liang, V. G. Agelidis, "A Novel Voltage Balancing Control Method for Flying Capacitor Multilevel Converters “, IEEE 29th Annual Conference of Industrial Electronics Society, Roanoke, USA, Vol. 2, pp. 1179-1184, 2003

[60] L. Xu, V. G. Agelidis, "A VSC Transmission System Using Flying Capacitor Multilevel Converters and Selective Harmonic Elimination PWM Control”, IEEE 7th International Power Engineering Conference, Singapore, Vol. 2, pp. 1176-1181, 2005

[61] A. K. Sadigh, S. H. Hosseini, M. Sabahi, G. B. Gharehpetian, "Double Flying Capacitor Multi cell Converter Based on Modified Phase-Shifted Pulse width Modulation", IEEE Transactions on Power Electronics, Vol. 25, No. 6, pp. 1517-1526, 2012

[62] A. Chen, L. Hu, X. He, "A Novel Type of Combined Multileve Converter Topologies", IEEE 30th Annual Conference of Industrial Electronics Society, Busan, South Korea, Vol. 3, pp. 2290-2294, 2004

[63] C. A. Teixeira, D. G. Holmes, B. P. McGrath, "Single-Phase SemiBridge Five-Level Flying-Capacitor Rectifier", IEEE Energy Conversion Congress and Exposition, Raleigh, North Carolina, pp. 337 344,2012

[64] Y. Shi, X. Yang, Q. He, Z. Wang, "Research on A Novel Capacitor Clamped Multilevel Matrix Converter", IEEE Transactions on Power Electronics, Vol. 20, No. 5, pp. 1055-1065, 2005

[65] T. Meynard, A. M. Lienhardt, G. Gateau, C. Haederli, P. Barbosa, "Flying Capacitor Multi Cell Converters with Reduced Stored Energy", IEEE International Symposium on Industrial Electronics, Montreal, Canada, Vol. 2, pp. 914-918, 2006

[66] M. Khazraei, H. Sepahvand, K. Corzine, M. Ferdowsi, "A Generalized Capacitor Voltage Balancing Scheme for Flying Capacitor Multilevel Converters", IEEE 25th Annual Applied Power Electronics Conference and Exposition, Palm Springs, California, pp. 58-62, 2010

[67] A .M. Y. M Ghias, M. Ciobotaru, A. Vassilios, , J. Pou, "Dynamic Behavior of A Back-to-Back Five-Level Flying Capacitor Converter with Reduced DC Bus Capacitance", IEEE 7th International Power Electronics and Motion Control Conference, Harbin, China, Vol. 3, pp. 1741-1746, 2012

[68] S. A. Khajehoddin, J. Ghaisari, A. Bakhshai, R. K. Jain, "A Novel Modeling and Analysis of Capacitor-Clamped Multilevel Converters", IEEE 37th Power Electronics Specialists Conference, Jeju, South Korea, pp. 1-5, 2006

[69] M. R. Islam, Y. Guo, J. Guo Zhu, "Performance and Cost Comparison of NPC, FC and SCHB Multilevel Converter Topologies for High-Voltage Applications", IEEE International Conference on Electrical Machines and Systems, Beijing, China, pp. 1-6, 2011

[70] J. Rodriguez, J. Sheng Lai, "Multilevel Inverters: A Survey of Topologies, Controls and Application", IEEE Transaction on Industrial Electronics, Vol. 49, No. 4, pp. 724-738, 2002

[71] D. Soto, R. Pena, L. Reyes, M. Vasquez, "A Novel Cascaded Multilevel Converter with A Single Non-isolated DC Link", IEEE 34th Annual Power Electronics Specialist Conference, Acapulco, Mexico, Vol. 4, pp. 1627-1632, 2003

[72] J. Ebrahimi, E. Babaei, G. B. Gharehpetian, "A New Topology of Cascaded Multilevel Converters with Reduced Number of Components for High-Voltage Applications", IEEE Transactions on Power Electronics, Vol. 26, No. 11, pp. 3109-3118, 2011 
[73] F. Z. Peng, J. W. Mckeever, D. J. Adams, "A Power Line Conditioner Using Cascade Multilevel Inverters for Distribution System”, IEEE Transaction on Industrial Electronics, Vol. 34, No. 6, pp. 1293-1298, 1998

[74] C. K. Lee, S. Y. R. Hui, H. S. H. Chung, “A 31 Level Cascaded Inverter for Power Applications", IEEE Transaction on Industrial Electronics, Vol. 49, No. 3, pp. 613-617, 2002

[75] X. Wen, N. Y. Dai, M. C. Wong, C. K. Wong, "Hybrid Cascaded Multilevel Converter for Medium-Voltage Large-Capacity Applications", IEEE Annual India Conference, Hyderabad, India, pp. 16,2011

[76] K. Wang, Y. Li, Z. Zheng, "A New Transformer less Cascaded Multilevel Converter Topology", IEEE Energy Conversion Congress and Exposition, San Jose, California, pp. 3124-3129, 2009

[77] R. Gupta, A. Ghoshb, A. Joshi, "Control of Cascaded Transformer Multilevel Inverter Based DSTATCOM", Electric Power Systems Research, Vol. 77, No. 8, pp. 989 - 999, 2006

[78] M. A. R. Shaikh, T. C. Green, "Technology Comparison for Cascaded Multilevel Converters in Distribution Networks", 3rd IET International Conference on Power Electronics, Machines and Drives, The Contarf Castle, Dublin, pp. 571-575, 2006

[79] I. Jaafar, F. B. Ammar, M. Elleuch, "Modelling and Control of Cascaded Multilevel Converters for Dynamic Compensation", The International Journal for Computation and Mathematics in Electrical and Electronic Engineering, Vol. 27, No. 5, pp. 1144-1161, 2008

[80] A. Kumar, R. Gupta, "Single-Phase AC/DC/AC Converter Using Cascaded Multilevel Inverter", IEEE International Conference on Power, Control and Embedded Systems, Allahabad, India, pp. 1-5, 2010

[81] S. Gautam, A. K. Yadav, R. Gupta, "AC/DC/AC Converter Based on Parallel AC/DC and Cascaded Multilevel DC/AC Converter", IEEE Students Conference on Engineering and Systems, Allahabad, India, pp. $1-6,2012$

[82] M. Carpaneto, M. Marchesoni, L. Vaccaro, “A New Cascaded Multilevel Converter Based on NPC Cells", IEEE International Symposium on Industrial Electronics, Vigo, Spain, pp. 1033-1038, 2007

[83] Y. Cheng, C. Qian, M. L. Crow, S. Pekarek, S. Atcitty, "A Comparison of Diode-Clamped and Cascaded Multilevel Converters for a STATCOM With Energy Storage", IEEE Transactions on Industrial Electronics, Vol. 53, No. 5, pp. 1512-1521, 2006

[84] S. A. Khajehoddin, A. Bakhshai, P. Jain, "The Application of the Cascaded Multilevel Converters in Grid Connected Photovoltaic Systems", IEEE Electrical Power Conference, Montreal, Canada, pp. 296-301, 2007

[85] S. Lu, K. A. Corzine, "Cascaded Multilevel Converters with Non-Integer or Dynamically Changing DC Voltage Ratios", CES/IEEE 5th International Power Electronics and Motion Control Conference, Shanghai, China, Vol. 1, pp. 1-5, 2006

[86] G. Mehlmann, F. Svensson, G. Herold, "18-Pulse Cascaded-MultilevelConverter", IEEE 11th International Conference on Electrical Power Quality and Utilization, Lisbon, Portugal, pp. 1-7, 2011

[87] E. Babaei, "A Cascade Multilevel Converter Topology with Reduced Number of Switches", IEEE Transactions on Power Electronics, Vol. 23, No. 6, pp. 2657-2664, 2008

[88] E. Babaei, S. H. Hosseini, "New Multilevel Converter Topology with Minimum Number of Gate Driver Circuits", IEEE International Symposium on Power Electronics, Electrical Drives, Automation and Motion, Ischia, pp. 792-797, 2008

[89] S. A. Gonzalez, M. I. Valla, C. F. Christiansen, "Analysis of a Cascade Asymmetric Topology for Multilevel Converters", IEEE International Symposium on Industrial Electronics, Vigo, Spain, pp. 1027-1032, 2007

[90] E. Babaei, S. H. Hosseini, G. B. Gharehpetian, M. Tarafdar Haquea, M. Sabahi, "Reduction of DC Voltage Sources and Switches in Asymmetrical Multilevel Converters Using A Novel Topology", Electric Power Systems Research, Vol. 77, No. 8, pp. 1073 - 1085, 2006

[91] C. O. Gercek, M. Ermis, "Elimination of Coupling Transformer Core Saturation in Cascaded Multilevel Converter Based T-STATCOM Systems", IEEE Transactions on Power Electronics, Vol. 29, No. 12, pp. $6796-6809,2014$
[92] Y. Xu, Y. Zou, "Research on a Novel Hybrid Cascade Multilevel Converter", IEEE International Power Engineering Conference, Singapore, pp. 1081-1085, 2007

[93] H. Akagi, "Classification, Terminology, and Application of the Modular Multilevel Cascade Converter (MMCC)", IEEE International Power Electronics Conference, Sapporo, Japan, pp. 508-515, 2010

[94] Z. Fu, “A Class of Cascade Multilevel Converters”, IEEE Conference on Industrial Electronics and Applications, Beijing, China, pp. 2369-2373, 2011

[95] X. Xu, Y. Zou, K. Ding, F. Liu, "Cascade Multilevel Inverter With Phase-Shift SPWM and Its Application in STATCOM", IEEE 30th Annual Conference of Industrial Electronics Society, Busan, South Korea, Vol. 2, pp. 1139-1143, 2004

[96] C. Zang, Z. Pei, J. He, G. Ting, J. Zhu, W. Sun, "Comparison and Analysis on Common Modulation Strategies for The Cascaded Multilevel STATCOM", International Conference on Power Electronics and Drive Systems, Taipei, Taiwan, pp. 1439-1442, 2009

[97] Z. Li, J. Wang, F. Zhang, B. Li, L. Qi, P. Xu, X. Xia, "Study of Harmonic Elimination in Switching Devices in STATCOM", IEEE 1st International Conference on Electric Power Equipment - Switching Technology, Xi'an, China, pp.224-228, 2011

[98] P. R. Surya, P. Malathy, "Design of Multilevel Inverter Based STATCOM for Power Quality Enhancement", IEEE International Conference on Advances in Engineering, Science and Management, Nagapattinam, India, pp. 144-149, 2012

[99] X. Fu, J. Wang, Y. Ji, “A Novel STATCOM Based on Cascaded Threephase Voltage Source Inverter", IEEE 32nd Annual Conference on Industrial Electronics, Paris, France, pp. 2174-2179, 2006

[100]Y. Li, B. Wu, "A Novel DC Voltage Detection Technique in the CHB Inverter-Based STATCOM", IEEE Transactions on Power Delivery, Vol. 23, No. 3, pp. 1613-1619, 2008

[101]D. Patel, R. Saravanakumar, K. K. Ray, R. Ramesh, "Design and Implementation of Three Level CHB Inverter With Phase Shifted SPWM Using TMS320F24PQ”, IEEE India International Conference on Power Electronics, Delhi, India, pp.1-6, 2011

[102]B. Mwinyiwiwa, Z. Wolanski, B. Ooi, "Current Equalization in SPWM FACTS Controllers at Lowest Switching Rates", IEEE 28th Annual Power Electronics Specialists Conference, St. Louis, Missouri, Vol. 1, pp. 325-330, 1997

[103]S. Zhonglai, Z. Guang, Z. Jinggang, "Research on Optimization Carrier Phase-Shifted SPWM Of Cascaded STATCOM", IEEE 2nd International Conference on Artificial Intelligence, Management Science and Electronic Commerce, Deng Leng, pp. 4252-4255, 2011

[104]E. Najafi, A. Yatim, A. S. Samosir, "A New Topology-Reversing Voltage (RV) for Multi Level Inverters", IEEE 2nd International Power and Energy Conference, Johor Bahru, Malaysia, pp.604-608, 2008

[105]Y. Liang, C. O. Nwankpa, “A New Type of STATCOM Based on Cascading Voltage-Source Inverters with Phase-Shifted Unipolar SPWM", IEEE Transactions on Industry Applications, Vol. 35, No. 5, pp. 1118-1123, 1999

[106]V. Spitsa, A. Alexandrovitz, E. Zeheb, "Robust Pole Placement Technique for STATCOM Controller Design", IEEE 25th Convention of Electrical and Electronics Engineers, Eilat, Israel, pp. 95-99, 2008

[107]B. S. Chen, Y. Y. Hsu, "An Analytical Approach to Harmonic Analysis and Controller Design of a STATCOM", IEEE Transactions on Power Delivery, Power Delivery, Vol. 22, No. 1, pp. 423-432, 2007

[108]N. M. Ali, V. Amin, "An LQR/Pole Placement Controller Design for STATCOM”, IEEE Control Conference, Hunan, China, pp.189-193, 2007

[109]A. F. Bati, "Damping Of Power Systems Oscillations by Using STATCOM GA-Based Optimal Controllers", IEEE/PES Conference on Innovative Smart Grid Technologies-Middle East, Jeddah, Saudi Arabia pp. 1-5, 2011

[110]B. S. Chen, Y. Y. Hsu, "A Minimal Harmonic Controller for a STATCOM", IEEE Transactions on Industrial Electronics, Vol. 55, No. 2, pp. 655-664, 2008 
[111]C. F. Xue, X. P. Zhang, K. R. Godfrey, "Design of STATCOM Damping Control with Multiple Operating Points: A Multimodal LMI Approach", IEEE Proceedings Generation, Transmission and Distribution, Vol. 153, No. 4, pp. 375-382, 2006

[112]W. Chao, Z. Yao, "Approach on Nonlinear Control Theory for Designing STATCOM Controller", IEEE International Conference on Grey Systems and Intelligent Services, Nanjing, China, pp. 871-875, 2007

[113]S. Latha, G.Y. R. Vikhram, "Power System Damping Improvement by Robust STATCOM Voltage Controller Design Using Loop-Shaping Technique", IEEE International Conference on Process Automation, Control and Computing, Coimbatore, India, pp. 1-6, 2011

[114]C. Li, Q. Jiang, Z. Wang, D. Retzmann, "Design of A Rule-Based Controller for STATCOM", IEEE 24th Annual Conference of the Industrial Electronics Society, Aachen, Germany, Vol. 1, pp. 467-472, 1998.

[115]C. Pang, M. Kezunovic, “A New Approach to PID Controller Design of STATCOM", IEEE 40th Power Symposium, Calgary, Canada, pp. 1-6, 2008

[116]C. H. Liu, Y. Y. Hsu, "Design of a Self-Tuning PI Controller for a STATCOM Using Particle Swarm Optimization", IEEE Transactions on Industrial Electronics, Vol. 57, No. 2, pp. 702-715, 2010.

[117]M. R. Banaei, "Enhancement of Power System Stability By Means Of SSSC and STATCOM: A Comparative Study", IEEE 7th International Conference on Electrical and Electronics Engineering, Bursa, Turkey, pp. 348-352, 2011

[118]S. M. Bamasak, M. A. Abido, "Assessment Study of Shunt FACTSBased Controllers Effectiveness on Power System Stability Enhancement", IEEE 39th International Universities Power Engineering Conference, Bristol, UK, Vol. 1, pp. 274-278, 2004

[119]H. Chen, J. Li, X. Zhou, "PSO-Based Self-Tuning PI Control for STATCOM", IEEE 7th International Power Electronics and Motion Control Conference, Harbin, China, Vol. 4, pp. 2710-2715, 2012

[120]R. Narne, J. P. Therattil, L. Sahu, P. C. Panda, "Dynamic Stability Enhancement Using Self-Tuning Static Synchronous Compensator", IEEE International Conference on Process Automation, Control and Computing, Coimbatore, India, pp. 1-5, 2011

[121]H. I. Shaheen, G. I. Rashed, S. J. Cheng, "Nonlinear Optimal Predictive Controller for Static Synchronous Compensator (STATCOM)", IEEE/PES Transmission and Distribution Conference and Exposition, Chicago, Illinois, pp.1-7, 2008

[122]B. Singh, R. Saha, "A New 24-Pulse STATCOM for Voltage Regulation", IEEE International Conference on Power Electronics, Drives and Energy Systems, Delhi, India, pp. 1-5, 2006

[123]P. Rao, M. L. Crow, Z. Yang, "STATCOM Control For Power System Voltage Control Applications", IEEE Transactions on Power Delivery, Vol. 15, No. 4, pp. 1311-1317, 2000

[124]S. Li, L. Xu, T. A. Haskew, "Control of VSC-Based STATCOM Using Conventional and Direct-Current Vector Control Strategies" International Journal of Electrical Power \& Energy Systems, Vol. 45, No. 1, pp. 175-186, 2012

[125]M. A. A. Malek, M. A. Abido "STATCOM Based Controller Design Using Particle Swarm Optimization for Power System Stability Enhancement", IEEE International Symposium on Industrial Electronics, Seoul, South Korea, pp. 1218-1223, 2009

[126]H. C. Tsai, C. C. Chu, S. H. Lee, "Passivity-based Nonlinear STATCOM Controller Design for Improving Transient Stability of Power Systems", IEEE Transmission and Distribution Conference \& Exhibition: Asia and Pacific, Dalian, China, pp. 1-5, 2005

[127]Y. Gui, Y. O. Lee, Y. Han, C. C. Chung, "Novel Passivity-Based Controller Design for Back-to-Back STATCOM with Asymmetrically Structured Converters", IEEE Power and Energy Society General Meeting, San Diego, California, pp. 1-6, 2012

[128]Y. Gui, Y. O. Lee, H. J. Kang, Y. Han, C. C. Chung, "Novel Passivity Based Controller Design For STATCOM", IEEE 11th International Conference on Control, Automation and Systems, Gyeonggi-do, South Korea, pp. 556-560, 2011
[129]H. C. Tsai, C. C. Chu, "Nonlinear STATCOM Controller using Passivity-Based Sliding Mode Control", IEEE Asia Pacific Conference on Circuits and Systems, Singapore, pp. 1996-1999, 2006

[130]E. C. Barrera, L. E. C. Ugalde, O. B. Ramos, "Design of A Digital Control System for A PWM-Based STATCOM", IEEE Electrical Power \& Energy Conference, Montreal, Canada ,pp. 1-6, 2009

[131]K. R. Padiyar, N. Prabhu, "Design and Performance Evaluation of Sub synchronous Damping Controller with STATCOM", IEEE Transactions on Power Delivery, Vol. 21, No. 3, pp. 1398-1405, 2006

[132]N. Voraphonpiput, S. Chatratana, "STATCOM Analysis and Controller Design for Power System Voltage Regulation", IEEE Transmission and Distribution Conference and Exhibition, Dalian, China, pp. 1-6, 2005

[133]Y. Xingwu, J. Jianguo, L. Shichao, “A Novel Design Approach of DC Voltage Balancing Controller for Cascaded H-Bridge Converter-Based STATCOM", IEEE 6th International Power Electronics and Motion Control Conference, Wuhan, China, pp. 2359-2364, 2009

[134]V. Spitsa, A. Alexandrovitz, E. Zeheb, "Design of a Robust State Feedback Controller for a STATCOM Using a Zero Set Concept", IEEE Transactions on Power Delivery, Vol. 25, No. 1, pp. 456-467, 2001

[135]D. Jovcic, R. Sternberger, "Robust Controller Design for a Multileve Cascaded STATCOM", IEEE Power and Energy Society General Meeting-Conversion and Delivery of Electrical Energy in the 21st Century, Pittsburgh, Pennsylvania, pp. 1-6, 2008

[136]Y. Shi, B. Liu, S. Duan, "Non Ideal Effect of Current Transformer and Its Influence on Controller Design of Cascade Multilevel STATCOM", IEEE 3rd International Symposium on Power Electronics for Distributed Generation Systems, Aalborg, Denmark, pp. 410-415, 2012

[137]P. S. Sensarma, K. R. Padiyar, V. Ramanarayanan, "Analysis and Performance Evaluation of A Distribution STATCOM for Compensating Voltage Fluctuations", IEEE Transactions on Power Delivery, Vol. 16, No. 2, pp. 259-264, 2001

[138]W. Song, Z. Yang, Y. Liu, A. H. B. Chen, "A Layered Modular Controller Structure for Multilevel Converters", IEEE Power Electronics Specialists Conference, Orlando, Florida, pp. 1448-1452, 2007

[139]K. Josh, A. Behal, A. K. Jain, N. Mohan, "A Comparative Study of Control Strategies for Fast Voltage Regulation with STATCOM", IEEE 30th Annual Conference of Industrial Electronics Society, Busan, South Korea, Vol. 1, pp. 187-192, 2004

[140]A. K. Jain, A. Behal, N. Mohan, "System Modeling and Control Design for Fast Voltage Regulation Using STATCOM", IEEE Transactions on Power Delivery, Vol. 21, No. 2, pp. 726-735, 2006

[141]A. K. Jain, A. B. Ximing T. Zhang, D. M. Dawson, N. Mohan, "Nonlinear Controllers for Fast Voltage Regulation Using STATCOM", IEEE Transactions on Control Systems Technology, Vol. 12, No. 6, pp. $827-842,2004$

[142]A. K. Jain, K. Joshi, A. Behal, N. Mohan, "Modelling and Nonlinear Control of STATCOMs for Fast Voltage Regulation", IEEE American Control Conference, Oregon, USA, pp. 1295-1300, 2005

[143]A. K. Jain, K. Joshi, A. Behal, N. Mohan, "Voltage Regulation with STATCOMS: Modelling, Control and Results", IEEE Transactions on Power Delivery, Vol. 21, No. 2, pp. 726-735, 2006

[144]B. Singh, V. S. Kadagala, "A New Configuration of Two-Level 48-Pulse VSCs Based STATCOM for Voltage Regulation", Electric Power Systems Research, Vol. 82, No. 1, pp. 11-17, 2011

[145]Y. Liu, A. Q. Huang, S. Bhattacharya, "Dead-Band Controller for Balancing Individual DC Capacitor Voltages in Cascade Multilevel Inverter Based STATCOM", IEEE 24th Annual Applied Power Electronics Conference and Exposition, Washington, USA, pp. 683-688, 2009

[146] Y. Liu, S. Bhattacharya, W. Song, A. Q. Huang, "Control Strategy for Cascade Multilevel Inverter Based STATCOM with Optimal Combination Modulation", IEEE Power Electronics Specialists Conference, Rhodes, Greece, pp. 4812-4818, 2008

[147]Y. Liu, S. Doss, W. Song, Q. Chen, S. S. Mundkur, T. Zhao, A. Q. Huang, S. Bhattacharya, "ETO Light Multilevel Inverter for STATCOM", IEEE 34th Annual Conference of Industrial Electronics, pp. 3246-3251, 2008 
[148]Y. Liu, A. Q. Huang, W. Song, S. Bhattacharya, G. Tan, "Small-Signal Model-Based Control Strategy for Balancing Individual DC Capacitor Voltages in Cascade Multilevel Inverter-Based STATCOM", IEEE Transactions on Industrial Electronics, Vol. 56, No. 6, pp. 2259-2269, 2009

[149]S. Mohagheghi, G. K. Venayagamoorthy, R. G. Harley, "Optimal Wide Area Controller and State Predictor for a Power System", IEEE Transactions on Power Systems, Vol. 22, No. 2, pp. 693-705, 2007

[150]H. Norouzi, A. M. Sharaf, "A Novel Control Scheme for the STATCOM Stability Enhancement", IEEE PES Transmission and Distribution Conference and Exposition, Dallas, Texas, Vol. 1, pp. 24-29, 2003

[151]S. K. Routray, N. Nayak, P. K. Rout, "An MIWO Based Approach of Power System Transient Stability Enhancement with STATCOM”, IEEE International Conference on Energy, Automation, and Signal, Bhubaneswar, India, pp. 1-7, 2011

[152]Y. O. Lee, H. J. Kang, Y. Han, C. C. Chung, "A Nonlinear Control for a BTB STATCOM System With Asymmetrically Structured Converters", IEEE Trondheim Power Tech., Trondheim, Norway, pp. 1-8, 2011

[153]A. H. M. A. Rahim, S. A. Al-Baiyat, H. M. Al-Maghrabi, "Robust Damping Controller Design for A Static Compensator", IEEE Proceedings Generation, Transmission and Distribution, Vol. 194, No. 4, pp. 491-496, 2002

[154]A. H. M. A. Rahim, S. A. Al-Baiyat, F. M. Kandlawala, "A Robust STATCOM Controller for Power System Dynamic Performance Enhancement" IEEE Power Engineering Society Summer Meeting, Vol. 2, Vancouver, Canada, pp. 887-892, 2001

[155]H. Zhang, Z. Zha, M. Zhang, X. Zha, "The Study on the Application of Repetitive Control in STATCOM", IEEE International Conference on Intelligent Computing and Intelligent Systems, Xiamen, China, Vol. 3, pp. 502-506, 2010

[156]H. X. Guo, Y. Q. Liu, J. Wu, J. M. Yang, “A Reinforcement Learning Approach to STATCOM Controller", IEEE International Conference on Electric Utility Deregulation, Restructuring and Power Technologies, Hong Kong, Vol. 2, pp. 638-642, 2004

[157]K. Kobayashi, M. Goto, K. Wu, Y. Yokomizu, T. Matsumura, "Power System Stability Improvement by Energy Storage Type STATCOM", IEEE Bologna Power Tech Conference Proceedings, Bologna, Italy, Vol. 2, 2003

[158]M. Saeedifard, R. Iravani, J. Pou, "Control and DC-Capacitor Voltage Balancing of A Space Vector-Modulated Five-Level STATCOM", IET Power Electronics, Vol. 2, No. 3, pp. 203-215, 2009

[159]M. Saeedifard, R. Iravani, J. Pou, "Analysis of a Space Vector Modulated Five-Level Converter", IEEE Power Engineering Society General Meeting, Tampa, Florida, pp. 1-8, 2007

[160]M. Saeedifard, R. Iravani, J. Pou, "A Space Vector Modulation Approach for a Back-to-Back Connected Four-Level Converter", IEE Power Electronics Specialists Conference, Orlando, Florida, pp. 20432049, 2007

[161]M. Saeedifard, R. Iravani, J. Pou, "Analysis and Control of DCCapacitor-Voltage-Drift Phenomenon of a Passive Front-End Five-Level Converter", IEEE Transactions on Industrial Electronics, Vol. 54, No. 6 , pp. 3255-3266, 2007

[162]R. Sternberger, D. Jovcic, "Analytical Modeling of A Square-Wave Controlled Cascaded Multilevel STATCOM", IEEE Transactions on Power Delivery, Vol. 24, No. 4, pp. 2261-2269, 2009

[163]R. Sternberger, D. Jovcic, "Theoretical Framework for Minimizing Converter Losses and Harmonics in a Multilevel STATCOM", IEEE Transactions on Power Delivery, Vol. 23, No. 4, pp. 2376-2384, 2008

[164]D. Jovcic, R. Sternberger, "Robust Controller Design for a Multilevel Cascaded STATCOM", IEEE Power and Energy Society General Meeting - Conversion and Delivery of Electrical Energy in the 21st Century, Pittsburgh, Pennsylvania, pp. 1-6, 2008

[165]Z. Yao, P. Kesimpar, V. Donescu, N. Uchevin, V. Rajagopalan, "Nonlinear Control for STATCOM Based on Differential Algebra", IEEE 29th Annual Power Electronics Specialists Conference, Vol. 1, Fukuoka, Japan, pp. 329-334, 1998

[166]M. M. Farsangi, Y. H. Song, Y. Z. Sun, "Supplementary Control Design of SVC and STATCOM Using Ho Optimal Robust Control", IEEE
International Conference on Electric Utility Deregulation and Restructuring and Power Technologies, London, UK, pp. 355-360, 2002

[167]M. M. Farsangi, Y. H. Song, W. L. Fang, X. F. Wang, "Robust FACTS Control Design Using The Ho Loop-Shaping Method", IEE Proceedings Generation, Transmission and Distribution, Vol. 149, No. 3, pp. 352358,2002

[168]S. Sirisukprasert, Y. Liu, Z. Xu, B. Zhang, X. Zhou, J. Hawley, A. Q. Huang, "Power Stage and Control Design for the ETO-Based CascadedMultilevel Converter for FACTS Applications", IEEE 4th International Power Electronics and Motion Control Conference, Xi'an,China, Vol. 3, pp. 1111-1117, 2004

[169]S. Sirisukprasert, A. Q. Huang, J. S. Lai, "Modeling, Analysis and Control of Cascaded-Multilevel Converter-Based STATCOM", IEEE Power Engineering Society General Meeting, Toronto, Canada, Vol. 4, pp. 2561- 2568, 2003

[170]M. T. Bina, D. C. Hamill, "Average Circuit Model for Angle-Controlled STATCOM", IEE Proceedings Electric Power Applications, Vol. 152, No. 3, pp. 653-659, 2005

[171]M. Mahdavian, G. Shahgholian, N. Rasti, "Modeling and Damping Controller Design for Static Synchronous Compensator", IEEE 6th International Conference on Electrical Engineering/Electronics, Computer, Telecommunications and Information Technology, Pattaya, Chonburi, Vol. 1, pp. 300-304, 2009

[172]J. Kumar, B. Das, P. Agarwal, "Indirect Voltage Control in Distribution System Using Cascade Multilevel Inverter Based STATCOM", IEEE International Conference on Power and Energy Systems, Chennai, India, pp. 1-6, 2011

[173]S. J. S. Tsai, Yun Chang, "Dynamic and Unbalance Voltage Compensation Using STATCOM", IEEE Power and Energy Society General Meeting - Conversion and Delivery of Electrical Energy in the 21st Century, Pittsburgh, Pennsylvania, pp. 1-8, 2008

[174]R. Milasi, A. Lynch, Y. W. Li, “Adaptive Control of a Voltage Source Converter for Power Factor Correction", IEEE Transactions on Power Electronics, Vol. PP, No. 99, pp. 1-24, 2012

[175]R. Milasi, A. F. Lynch, Y. Li, "Adaptive Control of a Voltage Source Converter", IEEE 23rd Canadian Conference on Electrical and Computer Engineering, Calgary, Canada pp. 1-4, 2010

[176]V. K. Chandrakar, A. G. Kothari, "Comparison of RBFN Based STATCOM, SSSC and UPFC Controllers for Transient Stability Improvement", IEEE/ PES Power Systems Conference and Exposition, Atlanta, Georgia, pp. 784-791, 2006

[177]G. Reed, R. Pape, M. Takeda, "Advantages of Voltage Sourced Converter (VSC) Based Design Concepts for FACTS and HVDC-Link Applications", IEEE Power Engineering Society General Meeting, Toronto, Canada, Vol. 3, pp. 1816-1821, 2003

[178]D. Soto, T. C. Green, “A DC Link Capacitor Voltages Control Strategy for a PWM Cascade STATCOM", IEEE 36th Power Electronics Specialists Conference, Jeju, South Korea, pp. 2251-2256, 2006

[179]D. Soto, T. C. Green, "A Comparison of High-Power Converter Topologies for the Implementation of FACTS Controllers", IEEE Transactions on Industrial Electronics, Vol. 49, No. 5, pp. 1072-1080, 2002

[180]D. Soto, T. C. Green, "Control of a Modular Multilevel Converter-Based HVDC Transmission System", IEEE 14th European Conference on Power Electronics and Applications, Birmingham, England, pp. 1-10, 2011

[181]R. E. Betz, T. J. Summers, B. J. Cook, "Outline of the Control Design for a Cascaded H-Bridge STATCOM", IEEE Industry Applications Society Annual Meeting, Edmonton, Canada, pp. 1-8, 2008

[182]R. E. Betz, B. J. Cook, T. J. Summers, R. Fisher, A. Bastiani, S. Shao, K. Willis, "Update on the Development of a Medium Voltage Multilevel Cascaded H-bridge STATCOM", IEEE Power Engineering Conference, Sydney, Australia, pp. 1-6, 2008

[183]R. E. Betz, B. J. Cook, T. J. Summers, R. Palmer, A. Bastiani, S. Shao, K. Willis, "Design and Development of an 11KV H-Bridge Multilevel STATCOM", IEEE Power Engineering Conference, Singapore, pp. 1-6, 2007 
[184]R. E. Betz, B. J. Cook, T. J. Summers, R. Fisher, A. Bastiani, S. Shao, P. Stepien, K. Willis, "Outline of the Design of a Cascaded H-bridge Medium Voltage STATCOM", IEEE 13th Power Electronics and Motion Control Conference, Poznan, Poland, pp. 1293-1300, 2008

[185]T. Kondo, A. Yokoyama, M. Goto, H. Konishi, M. Sekoguchi, Q. Lu, "Power System Transient Stability Enhancement by STATCOM with Nonlinear Control System", IEEE International Conference on Power System Technology, Kunming, China, Vol. 3, pp. 1908-1912, 2002

[186]W. A. Reass, D. L. Borovina, V. W. Brown, J. D. Doss, R. F. Gribble, T. W. Hardek, M. T. Lynch, D. E. Reeq, P. J. Tmllerico, "The Polyphase Resonant Converter Modulator System for the Spallation Neutron Source Linear Accelerator", IEEE 25th International Power Modulator Symposium, Hollywood, California, pp. 684-688, 2002

[187]F. S. Ismail, M. A. Abido, "The Impact of STATCOM Based Stabilizers on Power System Stability, Using Intelligent Computational Optimization Approach", IEEE Innovative Smart Grid Technologies, Anaheim, California, pp. 1-13, 2011

[188]B. Singh, R. Saha, "Enhancing Power Transfer Capacity of Transmission System by a Reduced Magnetics Based 48-Pulse STATCOM Controller", IEEE Joint International Conference on Power System Technology, Delhi, India, pp. 1-8, 2008
[189]M. G. Molina, P. E. .Mercado, E. H. Watanabe ,"Analysis of Integrated STATCOM-SMES Based on Three-Phase Three-Level Multi-Pulse Voltage Source Inverter for High Power Utility Applications", Journal of the Franklin Institute Vol. 348, Issue 9, pp. 2350-2377, 2011

[190]G. Narayanan, D. Zhao, H. K. Krishnamurthy, R. Ayyanar, V. T. Ranganathan, "Space Vector Based Hybrid PWM Techniques for Reduced Current Ripple", IEEE Transactions on Industrial Electronics, Vol. 55, No. 4, pp. 1614-1622, 2008

[191]G. Mondal, K. Gopakumar, P. N. Tekwani, E. Levi, "A ReducedSwitch-Count Five-Level Inverter with Common Mode Voltage Elimination for an Open-End Winding Induction Motor Drive”, IEEE Transactions on Industrial Electronics, Vol. 54, No. 4, pp. 2344-2351, 2007

[192]S. Mahadevan, S. Raju, R. Muthu, "Elimination of Common Mode Voltage Using Phase Shifted Dual Source Matrix Converter with Improved Modulation Index", The International Journal for Computation and Mathematics in Electrical and Electronic Engineering, Vol. 32, No. 6, pp. 2006-2026, 2013 